INDONESIA ACCOUNTING JOURNAL

VOLUME 2, NUMBER 2, YEAR 2020

${ }^{1}$ Corresponding author

Program Studi Akuntansi

Fakultas Ekonomi dan Bisnis

Universitas Pendidikan Nasional

Jl. Bedugul No. 39 Sidakarya

Denpasar, Indonesia, 80224

E-mail: agusfredym@undiknas.ac.id

Article info:

Received o9 February 2020

Accepted 11 February 2020

Available online 11 February 2020

Keywords: social and environmental accounting; Tri Hita Karana; corporate social responsibility; sustainability; spirituality

JEL Classification: E16, M14

DOI: http://doi.org/10.32400/iaj.27990

\section{Eksplorasi dimensi spiritual dalam praktik pelaporan akuntansi sosial dan lingkungan di Bali $\prec$}

\author{
Agus Fredy Maradona ${ }^{1}$
}

\begin{abstract}
Social and environmental accounting has attracted growing attention from companies in Indonesia as these companies face an increasing pressure to report their social and environmental responsibilities to the public. Despite this trend, however, Indonesia lacks a social and environmental reporting model that is relevant to its business environment, i.e., a model that incorporates the spiritual dimension, and not merely the economics, social, and environmental dimensions. The main aim of this study was to explore the spiritual dimension of the social and environmental reporting practices of a tourism company in Bali. The exploration was based on Tri Hita Karana, a local societal value held by the people of Bali. This study employed a two-phase research approach, where the first phase focused on exploring the social and environmental reporting practices of the company, while the second phase centered on refining and assessing the applicability of this reporting model in other companies. The results of this study show that the appropriate model of social and environmental accounting for Indonesian companies should consist of four dimensions: economic, environmental, social, and spiritual. Among these dimensions, the implementation of the spiritual dimension in social and environmental accounting faces the greatest challenges.
\end{abstract}

\section{Pendahuluan}

Prinsip hidup 'go green' atau 'environmentally friendly', yang memiliki makna menerapkan gaya hidup dengan menjaga kelestarian lingkungan, telah memperoleh dukungan luas dan menjadi sebuah standar etis baru dalam berbagai aspek kehidupan masyarakat. Meningkatnya perhatian terhadp isu-isu kelestarian lingkungan tidak terlepas dari semakin mengemukanya masalahmasalah lingkungan, seperti pemanasan global, perubahan iklim, pencemaran alam, dan lain sebagainya (Dryzek, Norgaard, \& Schlosberg, 2011; Chowdhary, Raj, \& Bharagava, 2018). Selain permasalahan di bidang lingkungan, dewasa ini isu-isu sosial juga semakin mendapat perhatian dari masyarakat luas. Isu sosial yang dimaksud terutamanya berkaitan dengan perlindungan terhadap hak-hak masyarakat dari eksternalitas negatif (negative externalities) yang timbul dari aktivitas bisnis (Weinzimmer \& Esken, 2016; Çelik, Arayici, \& Budayan, 2019; Chen, Vanclay, \& Zhang, 2019;
Rotondo, Corsi, \& Giovanelli, 2019). Perlindungan terhadap hak-hak masyarakat semakin dipandang penting mengingat masyarakat seringkali berada pada posisi yang dirugikan sebagai akibat dari dampak negatif aktivitas bisnis.

Meningkatnya perhatian masyarakat terhadap kelestarian lingkungan serta perlindungan terhadap hak-hak masyarakat telah mendorong semakin kuatnya tuntutan agar aktivitas perekonomian tidak saja mementingkan kinerja ekonomi melainkan juga harus memperhatikan dampak kegiatan ekonomi terhadap aspek sosial dan lingkungan. Perusahaan sebagai salah pelaku ekonomi dituntut untuk tidak lagi sematamata mengejar laba (profit) tetapi juga harus memberi kontribusi (benefit) bagi upaya penyelamatan lingkungan serta perlindungan terhadap hak-hak masyarakat (Foote, Gaffney, \& Evans, 2010; Isaksson, Kiessling, \& Harvey, 2014; Agudelo, Mauricio Andrés Latapí Johannsdottir \& Davidsdottir, 2019). Kondisi ini membawa pada semakin pentingnya konsep corporate 
social responsibility (CSR) di dalam dunia bisnis.

CSR merupakan suatu konsep yang bermakna melaksanakan kegiatan bisnis dengan cara-cara yang bertanggung jawab secara sosial, ekonomi, dan ekologi, di mana perusahaan memberi kontribusi positif kepada masyarakat dan makhluk hidup lain dalam aspek ekonomi, sosial, dan lingkungan melalui aktivitas bisnisnya (Aguinis \& Glavas, 2012). Guna mewujudkan prinsip bertanggung jawab secara sosial, ekonomi, dan ekologi ini, perusahaan pada umumnya melaksanakan aktivitas CSR dalam berbagai bentuk. Stakeholder suatu perusahaan berkepentingan terhadap informasi mengenai program CSR yang dilaksanakan oleh perusahaan bersangkutan karena stakeholder tidak lagi menilai kinerja perusahaan semata-mata dari kinerja ekonomi, tetapi juga berdasarkan kinerja dalam perspektif sosial dan lingkungan.

Di Indonesia, kewajiban perusahaan untuk melaksanakan program tanggung jawab sosial diatur melalui Undang-undang No. 40 tahun 2007 tentang Perseroan Terbatas. Selain adanya ketentuan mengenai kewajiban pelaksanaan aktivitas tanggung jawab sosial dan lingkungan, di dalam Undang-undang Perseroan Terbatas juga diatur kewajiban perusahaan untuk menyajikan laporan aktivitas tanggung jawab sosial dan lingkungan tersebut. Informasi mengenai aktivitas tanggung jawab sosial dan lingkungan suatu perusahaan pada umumnya diungkapkan melalui suatu mekanisme pelaporan akuntansi sosial dan lingkungan (social and environmental accounting atau SEA), yang dilaporkan melalui laporan tahunan atau melalui laporan khusus yang dikenal sebagai laporan keberlanjutan (sustainability report). Meski pelaksanaan aktivitas tanggung jawab sosial telah diwajibkan bagi sebagian perusahaan, hingga saat ini di Indonesia belum terdapat pedoman pelaporan SEA yang khusus digunakan oleh perusahaan di Indonesia sebagai panduan dalam menyusun laporan pengungkapan informasi tanggung jawab sosialnya. Perusahaan cenderung menggunakan pedoman pelaporan SEA yang berasal dari negara lain, seperti GRI Standards yang diterbitkan oleh Global Reporting Initiatives.

Selain itu, dibatasinya kewajiban pelaksanaan tanggung jawab sosial dan lingkungan dalam Undang-Undang Perseroan Terbatas hanya kepada perusahaan yang melaksanakan kegiatan usaha yang bersentuhan dengan sumber daya alam telah mengakibatkan lambatnya perkembangan pelaksanaan CSR di industriindustri lain, dimana salah satunya adalah industri pariwisata. Apabila dilihat dari karakteristik usahanya, industri pariwisata memang tidak melakukan eksplorasi sumber daya alam. Meskipun demikian, bukan berarti permasalahan sosial dan lingkungan tidak timbul sebagai dampak dari aktivitas industri pariwisata. Di Indonesia, salah satu daerah yang industri pariwisatanya sangat besar adalah Bali. Industri pariwisata di Bali telah berkembang sedemikian pesat, dan bisa dikatakan bahwa Bali merupakan daerah dengan industri pariwisata terbesar di Indonesia.

Ketiadaaan peraturan yang mewajibkan pelaksanaan aktivitas tanggung jawab sosial dan lingkungan di industri pariwisata telah mengakibatkan aktivitas CSR secara umum masih menjadi kegiatan voluntary atau sukarela bagi perusahaan pariwisata di Bali. Meskipun merupakan kegiatan sukarela, perkembangan terakhir menunjukkan bahwa semakin banyak perusahaan pariwisata di Bali yang melaksanakan kegiatan CSR. Berbagai hotel khususnya yang berskala internasional bahkan telah memasukkan tanggung jawab sosial dan lingkungan ke dalam standar pengelolaan kegiatan operasi sehari-hari.

Sayangnya, perkembangan pelaksanaan CSR di industri pariwisata di Bali tidak disertai dengan penyusunan pedoman pelaporan aktivitas tanggung jawab sosial dan lingkungan tersebut. Hingga saat ini pelaporan aktivitas CSR yang dilakukan oleh perusahaan pariwisata masih belum sistematis dan belum menyentuh aspek CSR secara komprehensif. Oleh karenanya, diperlukan studi yang mendalam untuk bisa 
mengidentifikasi area-area yang perlu untuk diungkapkan dalam laporan tanggung jawab sosial dan lingkungan perusahaan yang bergerak di bidang industri pariwisata di Bali.

Apabila dikaitkan dengan lingkungan sosial dan budaya di Indonesia, penekanan terhadap aspek ekonomi, sosial, dan lingkungan saja sesungguhnya belum cukup sebagai kerangka pelaporan aktivitas tanggung jawab sosial. Aspek ekonomi, sosial, dan lingkungan baru sebatas mengakomodasi pertanggungjawaban perusahaan terhadap sesama manusia dan terhadap lingkungannya. Sesuai dengan nilainilai yang dianut oleh masyarakat Indonesia, terdapat satu dimensi lain yang sangat penting untuk diakomodasi dalam konsep tanggung jawab sosial perusahaan, yaitu dimensi spiritualitas yang menyangkut pertanggungjawaban perusahaan (pengelolanya) kepada Sang Maha Pencipta.

Pentingnya menyertakan dimensi spiritual ke dalam aktivitas tanggung jawab sosial perusahaan telah disadari oleh berbagai perusahaan di Indonesia, termasuk oleh pelaku industri pariwisata di Bali. Perusahaan-perusahaan pariwisata ini telah melaksanakan aktivitas-aktivitas CSR yang tidak saja mencakup aspek sosial dan lingkungan, tetapi juga meliputi dimensi spiritual. Selain itu, sejumlah perusahaan pariwisata ini juga telah mengungkapkan informasi aktivitas tanggung jawab sosial ini melalui sejumlah media, seperti website perusahaan maupun laporan tahunan.

Namun demikian, meskipun dimensi spiritual telah mulai memberi warna bagi praktik pelaporan informasi sosial dan lingkungan perusahaan, hingga saat ini belum banyak penelitian yang mengeksplorasi keberadaan dimensi spiritual ini dalam praktik social and environmental accounting. Sejauh ini, sebagian besar penelitian yang telah terpublikasi pada umumnya lebih berfokus pada eksplorasi dimensi spiritual di dalam konteks pengembangan bisnis, tata kelola organisasi, manajemen sumber daya manusia, maupun budaya organisasi (lihat misalnya Weinberg \& Locander, 2014; Chawla, 2016; Kurt,
Yamin, Sinkovics, \& Sinkovics, 2016; Milliman, Gatling, \& Kim, 2018; dan Foster \& Foster, 2019). Oleh karenanya, untuk mengisi kekosongan di dalam literatur, penelitian ini bermaksud untuk mengeksplorasi bagaimana dimensi spiritual diwujudkan dalam praktik pelaporan tanggung jawab sosial perusahaan secara beriringan dengan dimensi ekonomi, sosial, dan lingkungan. Untuk dapat mengeksplorasi dimensi spiritual dalam praktik akuntansi sosial dan lingkungan secara mendalam, penelitian ini memilih fokus kajian berupa praktik pelaporan informasi tanggung jawab sosial oleh perusahaan pariwisata di Bali. Berangkat dari diskusi di atas maka tujuan utama dari penelitian ini adalah untuk mengeksplorasi praktik pelaporan akuntansi sosial dan lingkungan yang mencakup dimensi spiritual oleh perusahaan pariwisata di Bali.

\section{Tinjauan pustaka}

\section{Tanggung jawab sosial perusahaan}

Tanggung jawab perusahaan terhadap aspek-aspek sosial dan lingkungan dari aktivitasnya saat ini dikenal dengan istilah tanggung jawab sosial perusahaan atau corporate social responsibility (CSR). World Business Council for Sustainable Development mendefinisikan CSR sebagai komitmen berkelanjutan dari organisasi bisnis untuk melaksanakan aktivitasnya secara etis dan untuk berkontribusi terhadap pembangunan ekonomi seiring dengan meningkatkan kualitas hidup tenaga kerja, keluarga dari karyawannya, masyarakat local, serta masyarakat secara umum (Dahlsrud, 2008). Sementara itu, Commision of the European Communities memberikan definisi CSR sebagai sebuah konsep di mana perusahaan secara sukarela mengintegrasikan perhatian terhadap isu sosial dan lingkungan ke dalam aktivitas bisnisnya dan ke dalam interaksi perusahaan dengan stakeholder (Dahlsrud, 2008). Sejalan dengan dua definisi di atas, ISO Strategic Advisory Group on Social Responsibility mendefinisikan CSR sebagai " $a$ balanced approach for organizations to address economic, social and environmental issues in a way 
that aims to benefit people, communities and society" (Vasilescu, Barna, Epure, \& Baicu, 2010).

Tiga definisi CSR yang diuraikan di atas tampak memiliki makna yang sama, yaitu menyangkut bagaimana sebuah perusahaan (organisasi) menaruh perhatian dan tanggung jawab terhadap dimensi sosial dan lingkungan dari aktivitasnya. Keberlanjutan (sustainability) merupakan konsep utama yang mendasari CSR. Konsep sustainability menekankan pada konteks pembangunan yang berkelanjutan (sustainable development), yang didefinisi sebagai pembangunan yang memenuhi kebutuhan generasi saat ini tanpa mengganggu kemampuan generasi di masa depan untuk memenuhi kebutuhan mereka (World Commission on Environment and Development, 1987; Holden, Linnerud, \& Banister, 2014). Sustainable development adalah suatu proses perubahan di mana eksploitasi sumber daya, keputusan investasi, orientasi pengembangan teknologi, dan perubahan institusional semuanya selaras dan mampu meningkatkan potensi untuk memenuhi kebutuhan manusia saat ini maupun di masa mendatang. Konsep sustainability mencakup berbagai inisiatif perusahaan terkait dengan dampak lingkungan, program-program untuk karyawan, program pengembangan masyarakat, keselamatan konsumen, dan praktik perdagangan secara sehat (MouraLeite \& Padgett, 2011). Dengan demikian, pada dasarnya konsep sustainability dalam CSR ini berusaha untuk mensejajarkan aspek sosial dan lingkungan dengan aspek ekonomi dalam kegiatan perusahaan.

\section{Akuntansi sosial dan lingkungan}

Berkembangnya konsep sustainability dalam pengelolaan organisasi bisnis, yang berujung pada meningkatnya kesadaran perusahaan untuk melaksanakan aktivitas tanggung jawab sosial melalui programprogram CSR, telah meningkatkan perhatian terhadap mekanisme untuk mengkomunikasikan aktivitas tanggung jawab sosial perusahaan kepada para stakeholder-nya. Hal ini telah mendorong mengemukanya konsep akuntansi sosial dan lingkungan (social and environmental accounting atau SEA). SEA didefinisikan sebagai aktivitas penyusunan dan penyajian informasi yang bertujuan untuk menginformasi stakeholder suatu organisasi mengenai dampak organisasi bersangkutan terhadap masyarakat dan lingkungan di mana organisasi tersebut berada (Deegan, 2017). Akuntansi sosial dan lingkungan mencakup dimensi yang luas mengenai kinerja perusahaan, serta mengakomodasi kepentingan banyak stakeholder yang mempunyai kepentingan yang berbeda-beda. Dimensi-dimensi dari akuntansi sosial dan lingkungan tersebut meliputi perhatian kepada investor (dimensi ekonomi), fokus atas hubungan dengan masyarakat, serta perhatian terhadap lingkungan atau ekologi (Baldarelli, Baldo, \& Nesheva-Kiosseva, 2017). Pengukuran kinerja organisasi berdasarkan perspektif multidimensi dari akuntansi sosial dan lingkungan ini mengakibatkan adanya tambahan item pada pengukuran kinerja secara tradisional. Tambahan item pengukuran tersebut mencakup perhatian kepada konsumen, respon terhadap kondisi perekonomian, dampak lingkungan, serta aspek-aspek nonmoneter (Baldarelli et al., 2017).

Organisasi profesi akuntansi yang pertama kali menaruh perhatian terhadap akuntansi sosial dan lingkungan adalah The Accounting Standards Steering Committee of the Institute of Chartered Accountant in England yang menerbitkan The Corporate Report pada tahun 1975 (Baldarelli et al., 2017). Ketika itu, The Corporate Report ini menjadi panduan bagi perusahaan dalam mengungkapkan informasi terkait dengan aktivitas sosial dan lingkungan yang mereka laksanakan. Saat ini akuntansi sosial dan lingkungan terutama telah mengalami perkembangan yang signifikan, yang ditandai dengan semakin banyaknya perusahaan yang mengungkapkan informasi mengenai dampak sosial dan lingkungan dari aktivitas mereka (Deegan, 2017; Lehman, 2017). Perusahaanperusahaan ini menyajikan informasi akuntansi sosial dan lingkungan melalui laporan tahunan ataupun sustainability report yang berdiri sendiri (standalone) dari laporan tahunan.

Perkembangan akuntansi sosial dan lingkungan juga ditandai dengan semakin 
berkembangnya pedoman pengungkapan informasi sosial dan lingkungan. Di antara model-model pelaporan informasi akuntansi sosial dan lingkungan yang telah diterbitkan, model pelaporan yang diterbitkan oleh Global Reporting Initiatives, yaitu GRI Sustainability Reporting Standards yang merupakan model pelaporan paling banyak diterapkan (Gallego-Âlvarez, Lozano, \& Rodríguez-Rosa, 2018). GRI Sustainability Reporting Standards memberi pedoman pelaporan akuntansi sosial dan lingkungan yang meliputi tiga area pelaporan, yaitu ekonomi, lingkungan, dan sosial.

Disamping kemajuan dalam panduan pelaporan, perkembangan akuntansi sosial dan lingkungan juga terlihat dari semakin maraknya pelaksanaan assurance atas sustainability report perusahaan (Simnett, 2012). Assurance dilaksanakan untuk menentukan kesesuaian laporan dengan kriteria yang ditetapkan, serta untuk memastikan keandalan informasi di dalam laporan tersebut. Meskipun panduan pengungkapan informasi sosial dan lingkungan semakin berkembang serta telah banyak perusahaan yang melaksanakan assurance atas sustainability report-nya, pengungkapan informasi sesuai dengan pedoman tersebut maupun pelaksanaan assurance di berbagai negara sampai saat ini masih bersifat sukarela (voluntary).

\section{Riset-riset sebelumnya}

Penelitian yang berfokus pada isu praktik pelaporan akuntansi sosial dan lingkungan telah cukup banyak dilaksanakan. Sejumlah penelitian berusaha mengungkap faktor-faktor yang berpengaruh terhadap pengungkapan informasi tanggung jawab sosial dan lingkungan perusahaan. Sebagai contoh, penelitian Amidjaya \& Widagdo (2019), berdasarkan data dari perusahaan publik di industri perbankan di Indonesia, menunjukkan bahwa perusahaan cenderung memiliki laporan informasi tanggung jawab sosial dan lingkungan yang lebih baik ketika perusahaan tersebut memiliki tata kelola yang baik, terdapat kepemilikan investor asing di perusahaan, serta adanya kepemilikan keluarga dalam perusahaan. Sementara itu, penelitian mengenai alasan perusahaan mengungkapkan informasi sosial dan lingkungan telah pula dilaksanakan oleh sejumlah penelitian. Penelitian-penelitian ini pada umumnya menunjukkan bahwa perusahaan mengungkapkan informasi sosial untuk menciptakan image yang baik mengenai usahanya, sehingga pada gilirannya akan mampu meningkatkan kinerja keuangannya (Aguinis \& Glavas, 2012; Soobaroyen \& Ntim, 2013).

Sementara itu, penelitian-penelitian yang berfokus pada praktik pelaporan informasi dalam koridor akuntansi sosial dan lingkungan hingga saat ini masih sedikit dilaksanakan. Di antara sedikit penelitian tipe ini adalah penelitian-penelitian yang dilaksanakan oleh Jones (2011), Allen (2014), Dillard, Yuthas, \& Baudot (2016), dan Brown \& Tregidga (2017). Secara spesifik, Jones (2011) melakukan penelitian mengenai penggunaan grafik dalam laporan akuntansi sosial dan lingkungan, di mana penelitian ini menemukan bahwa grafik digunakan secara marak dalam laporan, bahkan juga digunakan sebagai sarana impression management. Allen (2014) melakukan sebuah kajian untuk mengembangkan kerangka akuntansi sosial dan lingkungan baru yang disebutnya sebagai new accounts, dengan penekanan pada aspek akuntabilitas yang lebih baik. Dillard et al. (2016) melakukan penelitian yang berfokus pada bagaimana sistem informasi akuntansi atas akuntansi sosial dan lingkungan dapat diimplementasikan pada lembaga keuangan mikro. Sementara itu, penelitian Brown \& Tregidga (2017) berfokus pada eksplorasi dimensi politis dari akuntansi sosial dan lingkungan.

Meskipun sejumlah penelitian telah mengkaji berbagai aspek dalam praktik pelaporan akuntansi sosial dan lingkungan, sejauh ini belum banyak penelitian yang berfokus untuk mengeksplorasi dimensi spiritual dari akuntansi sosial dan lingkungan. Padahal, dimensi spiritual telah dipandang sebagai suatu dimensi yang tidak dapat dipisahkan dari prinsip-prinsip tanggung jawab sosial perusahaan, khususnya perusahaan-perusahaan yang berada di negara yang nilai sosial 
masyarakatnya sangat kental dengan nuansa spiritual atau religius (Poulton \& Barnes, 2012; Muniapan \& Satpathy, 2013; Jamali \& Sdiani, 2013).

\section{Kerangka teoretis: Nilai budaya Bali Tri Hita Karana}

Penelitian ini berfokus pada eksplorasi dimensi spiritual dalam praktik pelaporan akuntansi sosial dan lingkungan. Oleh karenanya, diperlukan sebuah kerangka teoretis yang mampu menjadi lensa dalam memahami dimensi spiritual praktik pelaporan akuntansi sosial dan lingkungan di dalam setting penelitian. Istilah spiritualitas didefinisikan sebagai rasa untuk terhubung dengan diri yang utuh, makhluk lain, dan alam semesta (Krishnakumar \& Neck, 2002). Spiritualitas dapat pula didefinsiikan dalam konteks religius sebagai keyakinan mengenai adanya suatu entitas supranatural yang memiliki kekuatan atau kemampuan impersonal yang tak terbatas (Krishnakumar \& Neck, 2002). Sejalan dengan fokus penelitian untuk mengeksplorasi praktik pelaporan akuntansi sosial dan lingkungan perusahaan pariwisata di Bali, maka kerangka spiritual yang digunakan adalah konsep spiritual yang dianut oleh masyarakat Bali.

Kehidupan masyarakat Bali memang tidak bisa dilepaskan dari aspek religius, khususnya agama Hindu. Di dalam berbagai aktivitas keseharian yang dilaksanakan oleh masyarakat Bali senantiasa terlihat ritual keagamaan yang menunjukkan bahwa agama Hindu memang merupakan jiwa daripada budaya Bali (Wiana, 2004). Di dalam kebudayaan Bali yang bernafaskan nilai-nilai Hindu ini terdapat dua unsur, yaitu unsur yang supra-empiris yaitu wahyu Tuhan dan aspek empiris yaitu kebudayaan sebagai cara manusia untuk mengamalkan ajaran agama sesuai wahyu Tuhan (Wiana, 2004). Masyarakat Bali juga memegang teguh ajaran bahwa kebahagiaan (jagadhita) hanya dapat terwujud apabila tercipta hubungan yang harmonis antara manusia dengan Tuhan, manusia dengan sesama manusia, dan manusia dengan alam. Tiga hubungan yang harmonis ini dalam budaya Bali dikenal dengan konsep Tri Hita Karana (Roth \&
Sedana, 2015). Tri Hita Karana memiliki makna sebagai tiga penyebab kebahagiaan. Konsep Tri Hita Karana ini mengandung tiga nilai filosofis-spiritual, yaitu parbyangan, palemaban, dan pawongan (Wiana, 2007). Adapun makna yang terkandung dalam tiga nilai filosofis-spiritual tersebut adalah sebagai berikut ini.

Parbyangan merupakan nilai filosofisspiritual yang memiliki makna terciptanya hubungan yang harmonis antara manusia dengan Tuhan (Wiana, 2007). Secara nyata, nilai parbyangan ini diaktualisasikan oleh masyarakat Bali melalui berbagai aktivitas spiritual-religius yang dilakukan dalam rangka memuja kebesaran Tuhan. Dalam ajaran agama Hindu yang dianut oleh masyarakat Bali, terdapat empat cara atau empat jalan yang dapat digunakan dalam berhubungan dengan Tuhan guna mencapai kesempurnaan hidup. Empat jalan tersebut disebut dengan catur marga, yang terdiri dari bhakti marga, karma marga, jnana marga, dan raja marga (Suhardana, 2006).

Pawongan merupakan nilai filosofisspiritual yang memilikni makna terciptanya hubungan yang harmonis antara manusia dengan sesama manusia (Wiana, 2007). Masyarakat Bali memiliki ikatan sosial yang kuat dalam kehidupan sosialnya. Ikatan sosial ini tercermin dari konsep desa pekraman (desa adat) yang ada di Bali. Kuatnya hubungan sosial dalam masyarakat Bali sangat terlihat dari budaya gotong royong dalam melaksanakan berbagai aktivitas keagamaaan ataupun kegiatan adat. Dalam konteks ritual, filsafat hidup masyarakat Bali untuk menciptakan hubungan yang harmonis dengan sesama manusia tercermin dalam berbagai upacara keagamaan.

Palemahan adalah nilai filosofis-spiritual yang mengajarkan manusia untuk senantiasa menciptakan hubungan yang harmonis dengan alam (Wiana, 2007). Dalam budaya Bali, terdapat kepercayaan bahwa alam semesta tempat semua mahluk menjalani hidupnya ini dibangun oleh lima unsur yang disebut dengan Panca Maha Butha. Panca Maba Butha terdiri dari Prthivi (unsur padat), Apab (unsur cair), Teja (unsur panas), Bayu 
(unsur udara), dan Akasa (unsur ether) (Wiana, 2007). Alam semesta merupakan Bhuwana Agung sedangkan manusia yang tinggal di dalamnya adalah Bhuwana Alit. Dalam ajaran agama Hindu, Tuhan merupakan Jiwa dari pada Bhuwana Agung, dan percikanNya (yang disebut dengan Atman) merupakan jiwa dari pada Bhuwana Alit. Dengan demikian jelaslah bahwa dalam pandangan budaya Bali alam ini merupakan badan jasmani Tuhan. Karena pandangan ini maka masyarakat Bali sangat memercayai bahwa merusak alam ini sama dengan merusak badan jasmani Tuhan (Wiana, 2007).

\section{Metode penelitian}

\section{Pendekatan dan jenis penelitian}

Penelitian ini dilaksanakan melalui serangkaian proses penelitian bertahap yang melibatkan penelitian lapangan (field study) dan penelitian dokumen (documentary study). Tahap pertama penelitian merupakan penelitian lapangan yang melibatkan studi mendalam atas praktik pelaporan akuntansi sosial dan lingkungan di sebuah perusahaan pariwisata di Bali. Melalui studi lapangan ini berbagai asspek yang terkait dengan pelaksanaan pelaporan aktivitas tanggung jawab sosial dan lingkungan digali melalui metode penelitian yang relevan.

Sebagaimana telah disebutkan sebelumnya, penelitian ini berfokus pada eksplorasi praktik pelaporan aktivitas tanggung jawab sosial dan lingkungan perusahaan dari perspektif budaya Bali. Untuk mencapai tujuan dari penelitian ini, peneliti melakukan penelitian dengan pendekatan kualitatif dibawah paradigma interpretif. Landasan berpikir yang digunakan untuk memahami makna realitas adalah fenomenologi. Fenomenologi merupakan perspektif filosofi yang berusaha memahami arti peristiwa dan kaitankaitannya terhadap orang-orang yang berada dalam situasi-situasi tertentu (Patton, 2015).

Mengingat penelitian ini mengeksplorasi interaksi antara budaya Bali dengan akuntansi pertanggung jawaban sosial, maka peneliti menggunakan metode penelitian kebudayaan atau etnografi. Patton (2015) menyatakan bahwa etnografi merupakan suatu pendekatan untuk mendeskripsikan suatu kebudayaan, di mana tujuan utama pendekatan ini ini adalah untuk memahami suatu fenomena dari sudut pandang pelaku dalam fenomena tersebut. Dalam penelitian ini, etnografi mengandung makna memahami bagaimana masyarakat Bali mengorganisasikan budaya Bali dalam pikiran mereka dan kemudian menggunakan budaya tersebut sebagai landasan dalam menjalankan suatu organisasi dengan tetap melaksanakan tanggung jawab sosialnya.

Tahap lanjutan dalam penelitian ini merupakan tahap pengujian, yaitu pengujian keterterapan model pelaporan akuntansi tanggung jawab sosial dan lingkungan berbasis Tri Hita Karana. Pengujian dilakukan melalui telaah atas laporan tahunan ataupun sustainability report yang dipublikasikan oleh perusahaan yang relevan. Model pelaporan akuntansi sosial dan lingkungan yang dihasilkan melalui proses penelitian tahap pertama merupakan model pelaporan yang berbasis pada Tri Hita Karana. Oleh karenanya, dalam tahap lanjutan penelitian juga telah dilakukan serangkaian analisis terhadap kelayakan model pelaporan tersebut melalui sebuah focus group discussion. Selanjutnya, dilakukan eksaminasi atas keterterapan model ini dalam praktik pelaporan tanggung jawab sosial dan lingkungan perusahaan. Eksaminasi ini dilaksanakan melalui analisis konten atas laporan tahunan atau laporan keberlanjutan yang dipublikasikan oleh perusahaan yang tercatat di Bursa Efek Indonesia. Analisis konten merupakan sebuah metode penelitian yang dapat digunakan dalam tradisi penelitian kuantitatif maupun kualitatif (Neuman, 2014). Dalam pendekatan kualitatif, analisis konten menuntut peneliti untuk melaksanakan studi (telaah) atas isi dokumen sebagai media budaya (cultural media) yang yang memiliki makna sosial (Neuman, 2014).

\section{Setting penelitian}

Penelitian ini dilakukan pada sebuah perusahaan yang bergerak di bidang pengembangan pariwisata di salah satu kawasan pariwisata di Bali. Di dalam 
penelitian ini, perusahaan ini diberi nama samaran yaitu TourismCorp. Perusahaan ini memiliki kegiatan utama berupa mengelola salah satu kawasan pariwisata elit di Bali. TourismCorp dipilih sebagai setting penelitian karena penelitian ini berusaha untuk memahami dimensi spiritual dalam pelaporan akuntansi sosial dan lingkungan dari perspektif budaya Bali.

Selanjutnya, sebagaimana telah diuraikan di atas, tahap lanjutan penelitian ini melibatkan sebuah content analysis atas laporan keberlanjutan perusahaan yang listed di Bursa Efek Indonesia. Terdapat sejumlah alasan kenapa perusahaan yang tercatat di bursa digunakan di dalam penelitian ini. Pertama, perusahaan terbuka pada umumnya sangat terbuka atas informasi melalui laporan tahunan. Informasi tanggung jawab sosial dan lingkungan merupakan salah satu komponen informasi yang saat ini menjadi fokus utama pelaporan oleh perusahaan terbuka, sehingga laporan tahunan ataupun laporan keberlanjutan perusahaan-perusahaan tersebut mampu mencerminkan praktik pelaporan akuntansi sosial dan lingkungan yang berlaku umum di Indonesia saat ini. Kedua, informasi yang dipublikasikan oleh perusahaan terbuka pada umumnya telah melalui mekanisme verifikasi (misalnya audit atas laporan keuangan, review atas informasi tambahan dalam laporan tahunan, dan lain sebagainya), sehingga data yang diperoleh dari laporan tahunan tersebut adalah data yang akurat. Ketiga, pelaporan informasi oleh perusahaan terbuka seringkali dijadikan sebagai benchmark bagi pelaporan keuangan perusahaan pada umumnya (khususnya perusahaan berskala besar). Dengan mengeksaminasi model pelaporan akuntansi sosial dan lingkungan berbasis Tri Hita Karana pada perusahan terbuka maka transferability dari hasil penelitian ini akan lebih sahih.

\section{Penentuan informan}

Keberadaan informan dalam penelitian ini sangat penting, karena dalam penelitian dengan metode ethnografi, peneliti bekerja sama dengan informan untuk mendapatkan berbagai informasi yang diperlukan terkait dengan realitas yang diteliti. Informan merupakan pembicara asli (pemilik informasi asli) yang diminta oleh etnografer untuk berbicara dalam sudut pandangnya sendiri, sebagai sumber atas informasi yang dibutuhkan oleh etnografer (Patton, 2015). Informan merupakan sumber informasi yang membantu peneliti dalam menyelami kehidupan alamiah di setting penelitian, sehingga penting bagi peneliti untuk memilih informan yang tepat. Adapun para informan dalam penelitian ini adalah sebagai berikut: (1) direksi TourismCorp; (2) manajer bidang corporate communication di TourismCorp; (3) manajer bidang tanggung jawab sosial dan lingkungan TourismCorp; (4) pemilik dan/atau manajer perusahaan-perusahaan kecil dan menengah mitra usaha TourismCorp; (5) perwakilan karyawan TourismCorp; (6) Tokoh masyarakat di sekitar wilayah lokasi TourismCorp; dan (7) pakar budaya Bali.

\section{Tahap-tahap penelitian}

Penelitian ini dilakukan dengan mengikuti empat tahap mengikuti pola sebagaimana umumnya disarankan dalam literatur penelitian kualitatif (Patton, 2015). Empat tahap ini adalah tahap pra-lapangan, tahap pekerjaan lapangan, tahap analisis data, dan tahap penulisan laporan (Patton, 2015). Tahap pra-lapangan meliputi enam kegiatan, yaitu: menyusun rancangan penelitian; memilih lokasi penelitian (setting); mengurus perijinan; menjajaki dan menilai lapangan; memilih informan; dan menyiapkan perlengkapan penelitian (Patton, 2015). Tahap pekerjaan lapangan mencakup memahami latar penelitian dan persiapan diri; memasuki lapangan; dan mengumpulkan data dengan melakukan pengamatan berpartisipasi (Patton, 2015). Tahap analisis data dilakukan bersamaan dengan pekerjaan lapangan, yang meliputi open coding, axial coding, dan selective coding (Patton, 2015). Sementara itu, tahap penulisan laporan merupakan tahap di mana peneliti menuangkan hasil penelitian dalam bentuk laporan penelitian. 


\section{Hasil penelitian dan pembahasan \\ Hasil penelitian}

Dengan menggunakan nilai filosofis Tri Hita Karana, sebuah nilai kearifan lokal masyarakat Bali, sebagai kerangka teoritis, tahap pertama penelitian ini mengeksplorasi dimensi-dimensi dalam model pelaporan akuntansi tanggung jawab sosial dan lingkungan yang dilaksanakan oleh TourismCorp, yang didalamnya juga mencakup dimensi spiritual. Model pelaporan akuntansi tanggung jawab sosial dan lingkungan yang digunakan oleh perusahaan disebut dengan Akuntansi Tanggung Jawab Sosial dan Lingkungan Tri Hita Karana. Model tersebut meliputi dimensi ekonomi, sosial, lingkungan, dan spiritual. Berdasarkan penggalian atas nilai Tri Hita Karana sebagai pilar tanggung jawab sosial dan lingkungan perusahaan, model pelaporan yang digunakan oleh TourismCorp mengedepankan nilai Parbyangan, Palemahan, dan Pawongan.

Dalam focus group discussion, terungkap bahwa keterbatasan utama model pelaporan yang digunakan oleh TourismCorp adalah relevansinya dengan karakteristik bisnis di Indonesia serta dengan karakteristik sosialbudaya yang ada di masyarakat. Dari empat dimensi model pelaporan SEA Tri Hita Karana, yaitu ekonomi, sosial, lingkungan, dan spiritual, dimensi spiritual merupakan dimensi yang dipandang perlu untuk didefinisikan dengan lebih tegas. Dalam model pelaporan yang digunakan oleh TourismCorp, dimensi spiritualitas lebih menekankan aspek religiusitas dalam aktivitas bisnis suatu perusahaan. Dalam studi organisasional, upaya untuk memahami bagaimana individu mempertemukan nilainilai religius dengan kehidupan bisnis telah dipandang sebagai bidang kajian yang belum sepenuhnya tereksplorasi. Meski demikian, paling tidak ada tiga komponen utama dalam aspek religiusitas yang bias menjadi panduan dalam mengevaluasi model pelaporan SEA Tri Hita Karana, yaitu aspek koginitif (misalnya afiliasi dengan organisasi agama atau gerakan spiritual lainnya); aspek afektif (misalnya mengenai pentingnya agama dan nilai spiritualitas di tempat kerja), dan aspek-aspek perilaku (misalnya keikutsertaan dalam aktivitas keagamaan) (McGuire, Omer, \& Sharp, 2012).

Berdasarkan simpulan focus group discussion dirumuskan sejumlah revisi atas model pelaporan SEA Tri Hita Karana yang dikembangkan oleh TourismCorp. Revisi ini tidak mengakibatkan perubahaan mendasar dalam model pelaporan tersebut, tetapi bersifat memperhalus (refinement) untuk lebih menyesuaikan dengan kondisi bisnis dan sosial di Indonesia. Hasil refinement model pelaporan SEA Tri Hita Karana disajikan pada uraian-uraian berikut ini. Dimensidimensi pelaporan SEA Tri Hita Karana diawali dengan dimensi ekonomi. Dimensi ekonomi dalam laporan SEA Tri Hita Karana meliputi kontribusi ekonomi maupun dampak negatif suatu perusahaan terhadap sistem perekonomian pada tingkat lokal, nasional, dan internasional, yang menyangkut stakeholder yang luas. Terdapat dua indikator ekonomi yang dilaporkan dalam SEA Tri Hita Karana, yaitu: arus kapital (modal) di antara para stakeholder perusahaan; dan dampak ekonomi yang ditimbulkan oleh perusahaan terhadap masyarakat. Perlu untuk ditekankan bahwa kinerja keuangan merupakan indikator ekonomi yang dipandang sangat penting untuk dilaporkan kepada stakeholder perusahaan. Akan tetapi, karena aspek keuangan telah dilaporkan dalam laporan keuangan TourismCorp, maka manajemen berpendapat bahwa dalam laporan SEA Tri Hita Karana aspek keuangan itu tidak mendapat ruang pelaporan yang besar. Penekanan dimensi ekonomi dalam laporan SEA Tri Hita Karana yang dikembangkan oleh TourismCorp adalah pada aspek sejauh mana kontribusi perusahaan dalam meningkatkan kondisi perekonomian di masyarakat, yang juga mencakup peningkatan kesejahteraan rakyat.

Dimensi ekonomi dalam laporan SEA Tri Hita Karana terdiri dari tiga aspek, yaitu aspek kinerja ekonomi, aspek pasar tenaga kerja dan pemasok, dan aspek dampak ekonomi mikro. Aspek kinerja ekonomi diukur dengan menggunakan empat 
indikator, yaitu: (1) nilai ekonomi (value added) yang diperoleh dan didistribusikan kepada karyawan, masyarakat, pemilik modal, serta pemerintah; (2) dampak keuangan yang timbul sebagai akibat dari perubahan kondisi perekonomian; (3) pemenuhan kewajiban perusahaan terkait dengan imbalan pasca kerja atau program pensiun karyawan; dan (4) bantuan keuangan yang diterima dari pemerintah. Aspek pasar tenaga kerja dan pemasok diukur berdasarkan tiga indikator, yaitu: (1) perbandingan penghasilan minimum bagi karyawan pada entry level terhadap penghasilan minimum lokal yang ditetapkan oleh pemerintah daerah; (2) kebijakan perusahaan untuk membeli produk-produk dan bahan baku yang disediakan oleh pengusaha lokal khususnya usaha kecil dan menengah serta industri rumah tangga; dan (3) kebijakan perusahaan untuk merekrut karyawan dari unsur masyarakat lokal. Sementara itu, aspek dampak ekonomi makro diukur berdasarkan dua indikator, yaitu: (1) dampak signifikan perubahan kondisi ekonomi makro terhadap aktivitas perusahaan, khususnya yang mempengaruhi hubungan perusahaan dengan stakeholder, dan (2) upaya-upaya yang ditempuh oleh perusahaan untuk mengelola dampak perubahan kondisi ekonomi makro.

Dimensi sosial dalam SEA Tri Hita Karana meliputi pengungkapan informasi mengenai tanggung jawab perusahaan terhadap tenaga kerja; perlindungan hak asasi manusia; perlindungan terhadap hakhak masyarakat; dan perlindungan terhadap hak-hak pelanggan. Pada dimensi sosial ini, laporan SEA berbasis Tri Hita Karana yang disusun oleh TourismCorp mencakup aspek tanggung jawab terhadap tenaga kerja, tanggung jawab terhadap komponen masyarakat, dan aspek penghormatan terhadap hak asasi manusia. Terkait dengan tanggung jawab terhadap tenaga kerja, TourismCorp melaporkan informasi yang mencakup: (1) karakteristik tenaga kerja); (2) informasi hubungan antara karyawan dan manajemen; (3) informasi mengenai kesehatan dan keselamatan kerja; (4) informasi pengembangan sumber daya manusia; dan (5) kesetaraan di tempat kerja. Terkait dengan penghormatan terhadap hak asasi manusia, TourismCorp menyajikan informasi yang mencakup aspek: (1) pendidikan hak asasi manusia di perusahaan, yaitu total waktu yang dihabiskan untuk memberikan training kepada karyawan terkait dengan kebijakan dan prosedur perlindungan hak asasi manusia yang relevan dengan kegiatan operasi perusahaan; (2) aspek non-diskriminasi, yaitu kebijakan perusahaan untuk mencegah adanya diskriminasi di tempat kerja; (3) aspek kebebasan berserikat, yaitu perlindungan terhadap hak bagi karyawan untuk berserikat dan hasil-hasil yang telah dicapai oleh perusahaan dalam konteks hubungan dengan serikat pekerja; dan (4) aspek personel keamanan, yaitu adanya personel keamanan yang pengetahuan dan mendapat pelatihan hak asasi manusia yang relevan dengan aktivitas organisasi.

Terkait dengan tanggung jawab terhadap komponen masyarakat, TourismCorp melaporkan informasi yang mencakup: (1) aspek masyarakat lokal (yaitu kegiatan operasi perusahaan yang melibatkan masyarakat lokal, dampak negatif baik yang potensial maupun aktual dari aktivitas perusahaan terhadap masyarakat lokal, serta upaya pencegahan dampak negatif aktivitas perusahaan terhadap masyarakat lokal; (2) aspek good governance (mencakup analisis aktivitas usaha yang rentan terhadap risiko korupsi atau suap, pemberian pelatihan tentang sikap anti korupsi, dan sikap serta tindakan perusahaan sebagai respon atas terjadinya korupsi; (3) aspek politik, yang meliputi partisipasi perusahaan dalam pengembangan kebijakan publik dan kehidupan berpolitik serta bantuan keuangan dan bantuan dalam bentuk lainnya kepada partai politik atau politisi; dan (4) aspek kepatuhan terhadap hukum dan perundang-undangan, yang meliputi informasi mengenai risiko gugatan hukum yang dihadapi oleh perusahaan dan sanksi yang ditanggung oleh perusahaan karena tidak mematuhi hukum perundangundangan. 
Dimensi lingkungan dalam laporan SEA Tri Hita Karana yang disusun oleh TourismCorp berfokus pada pengungkapan informasi mengenai dampak aktivitas perusahaan terhadap lingkungan alam, termasuk di dalamnya adalah ekosistem, tanah, udara, dan air. Indikator kinerja lingkungan yang digunakan meliputi kinerja yang terkait dengan input (misalnya material, energi, dan air) dan output (misalnya emisi dan limbah). Dimensi lingkungan juga mencakup indikator kinerja terkait dengan alih fungsi lahan, kepatuhan terhadap regulasi mengenai lingkungan, serta dampak lingkungan dari produk dan jasa yang dihasilkan oleh organisasi. Informasi dalam dimensi lingkungan yang dilaporkan perusahaan dalam laporan SEA Tri Hita Karana adalah mencakup sejumlah aspek, yaitu: (1) aspek material, yaitu jenis material, sumber, dan deskripsi tentang material yang digunakan, dalam kegiatan perusahaan, material yang merupakan hasil daur ulang, serta material yang memiliki isu sensitif berkaitan dengan nilai-nilai masyarakat lokal; (2) aspek energi, yaitu jenis energy yang digunakan secara langsung maupun tidak langsung oleh perusahaan serta banyaknya penggunaan, energi yang telah dihemat oleh perusahaan sebagai bentuk efisiensi sesuai dengan program efisiensi di perusahaan, dan kebijakan perusahaan untuk menyediakan produk dan layanan hemat energi atau produk dan jasa berbasis energi terbarukan; (3) aspek penggunaan air, meliputi informasi tentang banyaknya volume air yang digunakan oleh perusahaan yang diklasifikasikan sesuai dengan sumbernya, sumber air yang secara signifikan terkena dampak eksplorasi air oleh organisasi, dan persentase dan total volume air yang didaur ulang (recycled) dan digunakan kembali (reused); (4) aspek alih fungsi lahan, yaitu lokasi dan luas lahan yang dimiliki, disewa, dikelola, atau dikuasai oleh perusahaan yang sebelumnya merupakan lahan yang ditujukan untuk areal persawahan, perkebunan, ataupun jenis lahan produktif lainnya; (5) aspek limbah dan sampah, mencakup total air yang dibuang yang diklasifikasikan berdasarkan kualitas dan destinasi pembuangan, total berat sampah yang dibuang yang diklasifikasikan berdasarkan tipe sampah dan metode pembuangan, kebijakan perusahaan untuk menghentikan dampak lingkungan dari produk dan jasa, serta sinergi perusahaan dengan masyarakat lokal dalam pengolahan sampah.

Akhirnya, dimensi terakhir dari laporan SEA Tri Hita Karana yang dikembangkan oleh TourismCorp adalah dimensi spiritual. Dimensi spiritual dalam SEA Tri Hita Karana ini mencakup tiga aspek utama, yaitu aspek donasi dalam konteks kerohanian, aspek spiritualitas di tempat kerja, dan aspek 3) kehidupan beragama dan pluralism di masyarakat. Terkait dengan aspek donasi dalam konteks kerohanian, perusahaan melaporkan informasi yang beberapa hal. Pertama adalah jumlah sumbangan (dana punia) serta sumbangan keagamaan dengan istilah lain yang disumbangkan oleh perusahaan kepada organisasi-organisasi kerohanian, tempat ibadah, desa adat, dan organisasi lain yang terkait. Kedua, perusahaan melaporkan informasi mengenai sinergi perusahaan dengan lembaga masyarakat lokal, kelompok masyarakat adat, dan organisasi keagamaan dalam penentuan kebijakan strategis terkait dengan sumbangan keagamaan yang diberikan oleh perusahaan. Ketiga, sebagai bentuk tanggung jawab holistik perusahaan, perusahaan juga menyajikan informasi mengenai tindak lanjut dari sumbangansumbangan keagamaan yang diberikan, terutama dampaknya terhadap keamajuan kehidupan spiritual di masyarakat.

Terkait dengan aspek spiritualitas di tempat kerja, perusahaan menyajikan informasi mengenai penyediaan tempat ibadah di tempat kerja untuk seluruh agama yang dianut oleh karyawan, informasi tentang kebijakan dan upaya perusahaan dalam menjamin kebebasan beragama di tempat kerja, informasi tentang penghormatan terhadap hak-hak untuk melaksanakan kehidupan beragama bagi seluruh personel perusahaan, pelaksanaan aktivitas kerohanian dan spiritual di tempat kerja, serta pelaksanaan program-program guna meningkatkan religiusitas atau 
spiritualitas dalam kehidupan organisasi perusahaan. Selanjutnya, terkait dengan aspek kehidupan beragama dan pluralism di masyarakat, perusahaan menyajikan informasi mengenai kontribusi perusahaan bagi aktivitas perlindungan hak-hak beragama di masyarakat, peran serta perusahaan dalam menunjang aktivitasaktivitas keagamaan masyarakat lokal, serta dukungan perusahaan terhadap pluralism dalam masyarakat, khususnya yang terkait dengan pelaksanaan keyakinannya terhadap Tuhan Yang Maha Esa.

\section{Pembahasan}

Content analysis terhadap sejumlah laporan tahunan yang dipublikasikan oleh perusahaan yang tercatat di Bursa Efek Indonesia menunjukkan bahwa sejumlah dimensi pelaporan sebagaimana diuraikan dalam model pelaporan SEA Tri Hita Karana telah dilaporkan oleh perusahaanperusahaan terbuka di Indonesia. Di antara perusahaan yang mempublikasikan informasi tanggung jawab sosial dalam laporan tahunannya, ataupun dalam laporan khusus standalone sustainability report, jenis perusahaan yang lebih banyak mengungkapkan informasi tanggung jawab sosial dan lingkungan adalah perusahaan yang bergerak di bidang eksplorasi alam maupun perusahaan yang memproduksi consumer products. Hal ini dapat dimaklumi mengingat perusahaan-perusahaan tersebut memiliki dampak lingkungan yang besar dari aktivitasnya, misalnya dampak dari eksplorasi alam maupun dampak dari pencemaran lingkungan dari sampah kemasan barang konsumer.

Analisis atas jenis industri yang melaporkan informasi tanggung jawab sosial dan lingkungan mengungkap sebuah fenomena bahwa praktik pelaporan social dan environmental accounting saat ini lebih dimaknai sebagai tanggung jawab lingkungan. Meskipun dimensi lingkungan memang merupakan salah satu dimensi dalam pelaksanaan CSR dan pelaporannya, namun aspek lingkungan bukan satu-satunya dimensi CSR. Oleh karenanya, perhatian terhadap aspek ekonomi, sosial, dan spiritual dalam pelaksanana dan pelaporan aktivitas tanggung jawab sosial dan lingkungan merupakan isu khusus yang perlu untuk dieksplorasi.

Investigasi atas laporan tahunan perusahaan melalui content analysis mengungkap bahwa dimensi spiritual merupakan sebuah isu yang perlu mendapat perhatian dalam konteks program tanggung jawab sosial dan lingkungan serta pelaporan informasi aktivitas tanggung jawab sosial dan lingkungan perusahaan. Praktik yang diterapkan saat ini menunjukkan rendahnya pengungkapan informasi tanggung jawab sosial dan lingkungan yang bisa dikategorikan ke dalam dimensi spiritual. Sejumlah aktivitas sosial-adat-religius yang bisa dikategorikan secara longgar ke dalam dimensi spiritual tampaknya masih bercampur aduk dengan aktivitas sosial, yang menunjukkan belum tegasnya pemahaman perusahaan-perusahaan mengenai batasan-batasan dimensi sosial dan dimensi spiritual. Hal ini mengakibatkan perusahaan lebih banyak menyajikan informasinya ke dalam komponen aktivitas sosial. Keseluruhan isu ini membawa tantangan bagi aplikasi model pelaporan SEA Tri Hita Karana yang telah dikembangkan oleh TourismCorp untuk mampu memberi definisi yang lebih tegas atas dimensi spiritual dalam tanggung jawab sosial dan lingkungan guna memberi batasan yang mudah dipahami yang membedakannya dengan dimensi sosial.

\section{Kesimpulan dan saran Kesimpulan}

Tujuan utama penelitian ini adalah mengeksplorasi dimensi spiritual dalam praktik pelaporan informasi tanggung jawab sosial dan lingkungan oleh perusahaan pariwisata di Bali. Eksplorasi dilakukan dengan menggunakan nilai budaya Bali sebagai sebuah lensa teoritis. Adapun nilai budaya masyarakat Bali yang digunakan di dalam penelitian ini adalah Tri Hita Karana, sebuah nilai filosofis spiritual yang dianut oleh masyarakat Bali. Eksplorasi dilakukan atas model pelaporan akuntansi sosial dan lingkungan Tri Hita Karana yang dikembangkan oleh TourismCorp, sebuah 
perusahaan terkemuka nasional yang berdomisili di Bali sebagai pengelola kawasan wisata terencana di Bali.

Untuk dapat menyertakan dimensi spiritualitas ke dalam landasan akuntansi sosial dan lingkungan diperlukan suatu nilai kultur-religius masyarakat yang bersifat universal. Konsep Tri Hita Karana dalam budaya Bali merupakan nilai budaya yang sangat tepat untuk tujuan ini. Tri Hita Karana merupakan suatu nilai filosofis yang bersifat universal mengenai keharmonisan hubungan antara manusia dengan Tuhan, manusia dengan sesama manusia, dan manusia dengan lingkungannya. Oleh karena itu, model pelaporan akuntansi sosial dan lingkungan yang telah dieksplorasi di dalam penelitian ini dapat menjadi model pelaporan berbasis Tri Hita Karana yang dapat dijadikan acuan bagi perusahaan.

Berdasarkan analisis yang telah dilaksanakan berdasarkan pendekatan studi kualitatif, penelitian ini berhasil menelusuri esensi model pelaporan akuntansi tanggung jawab sosial dan lingkungan perusahaan yang berbasis Tri Hita Karana. Adapun substansi dari model pelaporan ini adalah empat dimensi, yaitu dimensi ekonomi, dimensi sosial, dimensi lingkungan, dan dimensi spiritual. Dimensi ekonomi dalam laporan SEA Tri Hita Karana meliputi dampak ekonomi suatu perusahaan terhadap sistem perekonomian pada tingkat lokal, nasional, dan internasional, yang menyangkut stakeholder yang luas. Terdapat dua indikator ekonomi yang dilaporkan dalam SEA Tri Hita Karana, yaitu arus kapital di antara para stakeholder perusahaan dan dampak ekonomi yang ditimbulkan oleh perusahaan terhadap masyarakat. Dimensi sosial dalam SEA Tri Hita Karana meliputi pengungkapan informasi mengenai tanggung jawab perusahaan terhadap tenaga kerja, perlindungan hak asasi manusia, perlindungan masyarakat; dan perlindungan pelanggan. Dimensi lingkungan dalam laporan SEA Tri Hita Karana berfokus pada pengungkapan informasi mengenai dampak organisasi terhadap alam. Sementara itu, dimensi spiritual dalam SEA Tri Hita Karana mencakup sejumlah komponen pelaporan, yaitu donasi dalam konteks kerohanian; spiritualitas di tempat kerja; serta kehidupan beragama dan pluralism di masyarakat.

\section{Saran}

Terdapat sejumlah keterbatasan dalam penelitian ini yang bisa menjadi masukan bagi penelitian berikutnya. Adapun keterbatasan tersebut adalah sebagai berikut. Pertama, dalam pemilihan lokasi penelitian, penelitian ini memilih perusahaan yang aktivitas usahanya adalah mengelola kawasan pariwisata yang sangat terencana (well-planned tourism area) di Bali. Alasan utama penelitian dilaksanakan di setting ini adalah karena perusahaan melaksanakan program tanggung jawab sosial dan melaporkan informasinya secara terstruktur dan jelas. Meski demikian, pemilihan lokasi penelitian ini mengakibatkan adanya kelemahan, yaitu ada kemungkinan terjadi bias dalam hasil penelitian yang disebabkan oleh regulasi khusus bagi perusahaan tipe ini. Kedua, penelitian ini mengeksplorasi landasan konseptual akuntansi sosial dan lingkungan yang berbasis pada nilai Tri Hita Karana dalam bentuk dimensi ekonomi, sosial, lingkungan, dan spiritual. Dalam implementasi landasan konseptual ini, terdapat perdebatan mengenai apakah implementasinya tetap dalam tiga dimensi yaitu spiritual-ekonomi, sosio-spiritual, dan ekologi-spiritual; ataukah diimplementasikan dalam empat dimensi yaitu ekonomi, sosial, lingkungan, dan spiritual. Penelitian ini merumuskan model SEA Tri Hita Karana dengan pendekatan yang disebut terakhir saja, tanpa mengakomodasi pendekatan yang disebutkan pertama. Ketiga, dalam merumuskan implementasi dimensi spiritual dalam pelaksanaan pelaporan akuntansi sosial dan lingkungan, penelitian ini membedakan antara aktivitas yang bisa diukur secara langsung dalam satuan moneter dan aktivitas yang tidak dapat diukur secara langsung dalam satuan moneter. Hingga saat ini belum ada kesepakatan mengenai batasan dimensi spiritualitas dalam konteks tanggung jawab perusahaan, sehingga penelitian ini hanya 
mendasarkan pada konsep spiritualitas di tempat kerja (workplace spirituality).

Berdasarkan keterbatasan-keterbatasan penelitian yang telah diuraikan di atas, terdapat sejumlah saran yang dapat diikuti bagi penelitian selanjutnya. Pertama, penelitian berikutnya dapat mempertimbangkan untuk memilih lokasi penelitian pada perusahaan atau organisasi yang tidak memiliki regulasi spesifik bagi jenis organisasi bersangkutan, khususnya regulasi yang terkait dengan CSR. Hal ini ditujukan untuk menghidari adanya bias regulasi yang dapat memengaruhi motivasi sebuah organisasi untuk melaksanakan praktik tanggung jawab sosial perusahaan. Kedua, penelitian berikutnya dapat dirancang untuk menganalisis praktik pelaporan akuntansi tanggung jawab sosial dan lingkungan dalam tiga dimensi, yaitu ekonomi, sosial, dan lingkungan, yang di dalamnya terkandung nilai spiritualisme secara intrinsik atau inklusif. Ketiga, diperlukan studi yang mendalam yang ditujukan untuk mengidentifikasi, memberi definisi, dan mengukur kinerja spiritual dari suatu organisasi. Studi ini diperlukan agar dimensi spiritual dalam praktik corporate social responsibility maupun pelaporan informasinya melalui akuntansi sosial dan lingkungan memiliki parameter yang jelas.

\section{Daftar pustaka}

Agudelo, M. A. L., Johannsdottir, L., \& Davidsdottir, B. (2019). Drivers that motivate energy companies to be responsible: A systematic literature review of corporate social responsibility in the energy sector. Journal of Cleaner Production, 247, 119094. https://doi.org/10.1016/j.jclepro.2019.119094

Aguinis, H., \& Glavas, A. (2012). What we know and don't know about corporate social responsibility: A review and research agenda. Journal of Management, 38(4), 932-968.

https://doi.org/10.1177/0149206311436079

Allen, B. G. (2014). What's new about New accounts? Assessing change proposals for social and environmental accounting. Accounting Forum, 38(4), 278-287.

https://doi.org/10.1016/j.accfor.2014.03.001

Amidjaya, P. G., \& Widagdo, A. K. (2019). Sustainability reporting in Indonesian listed banks: Do corporate governance, ownership structure and digital banking matter? Journal of Applied Accounting Research, Forthcomin. https://doi.org/10.1108/JAAR-09-20180149

Baldarelli, M.-G., Baldo, M. Del, \& Nesheva-Kiosseva, N.
(2017). Environmental Accounting and Reporting: Theory and Practice. Cham, Switzerland: Springer.

Brown, J., \& Tregidga, H. (2017). Re-politicizing social and environmental accounting through Rancière: On the value of dissensus. Accounting, Organizations and Society, 61, 1-21. https://doi.org/10.1016/j.aos.2017.08.002

Celik, T., Arayici, Y., \& Budayan, C. (2019). Assessing the social cost of housing projects on the built environment: Analysis and monetization of the adverse impacts incurred on the neighbouring communities. Environmental Impact Assessment Review, 77, 1-10. https://doi.org/10.1016/j.eiar.2019.03.001

Chawla, V. (2016). Workplace spirituality governance: impact on customer orientation and salesperson performance. Journal of Business \& Industrial Marketing, 31(4), 498-506. https://doi.org/10.1108/JBIM-08-2014-0153

Chen, C., Vanclay, F., \& Zhang, Y. (2019). The social impacts of a stop-start transnational university campus: How the impact history and changing plans of projects affect local communities. Environmental Impact Assessment Review, 77, 105-113. https://doi.org/10.1016/j.eiar.2019.04.004

Chowdhary, P., Raj, A., \& Bharagava, R. N. (2018). Environmental pollution and health hazards from distillery wastewater and treatment approaches to combat the environmental threats: A review. Chemosphere, 194, 229-246. https://doi.org/10.1016/j.chemosphere.2017.11.16 3

Dahlsrud, A. (2008). How corporate social responsibility is defined: An analysis of 37 definitions. Corporate Social Responsibility and Environmental Management, 15(1), 113. https://doi.org/10.1002/csr.132

Deegan, C. (2017). Twenty five years of social and environmental accounting research within Critical Perspectives of Accounting: Hits, misses and ways forward. Critical Perspectives on Accounting, 43, 65-87. https://doi.org/10.1016/j.cpa.2016.06.005

Dillard, J., Yuthas, K., \& Baudot, L. (2016). Dialogic framing of accounting information systems in social and environmental accounting domains: Lessons from, and for, microfinance. International Journal of Accounting Information Systems, 23, 14-27. https://doi.org/10.1016/j.accinf.2016.10.001

Dryzek, J. S., Norgaard, R. B., \& Schlosberg, D. (2011). The Oxford Handbook of Climate Change and Society. Oxford University Press.

Foote, J., Gaffney, N., \& Evans, J. R. (2010). Corporate social responsibility: Implications for performance excellence. Total Quality Management and Business Excellence, 21(8), 799-812. https://doi.org/10.1080/14783363.2010.487660

Foster, S., \& Foster, A. (2019). The impact of workplace spirituality on work-based learners : Individual and organisational level perspectives. Journal of WorkApplied Management, 11(1), 63-75. https://doi.org/10.1108/JWAM-06-2019-0015

Gallego-Álvarez, I., Lozano, M. B., \& Rodríguez-Rosa, M. (2018). An analysis of the environmental information in international companies according to the new GRI standards. Journal of Cleaner Production, 182 , $57-66$. https://doi.org/10.1016/j.jclepro.2018.01.240

Holden, E., Linnerud, K., \& Banister, D. (2014). Sustainable development: Our Common Future 
revisited. Global Environmental Change, 26, 130-139. https://doi.org/10.1016/j.gloenvcha.2014.04.006

Isaksson, L., Kiessling, T., \& Harvey, M. (2014). Corporate social responsibility: Why bother? Organizational Dynamics, 43(1), 64-72. https://doi.org/10.1016/i.orgdyn.2013.10.008

Jamali, D., \& Sdiani, Y. (2013). Does religiosity determine affinities to CSR? Journal of Management, Spirituality and Religion, 10(4), 309-323. https://doi.org/10.1080/14766086.2013.802251

Jones, M. J. (2011). The nature, use and impression management of graphs in social and environmental accounting. Accounting Forum, 35(2), 75-89. https://doi.org/10.1016/j.accfor.2011.03.002

Krishnakumar, S., \& Neck, C. P. (2002). The "what", "why" and "how" of spirituality in the workplace. Journal of Managerial Psychology, 17(3), 153-164. https://doi.org/10.1108/02683940210423060

Kurt, Y., Yamin, M., Sinkovics, N., \& Sinkovics, R. R. (2016). Spirituality as an antecedent of trust and network commitment: The case of Anatolian Tigers. European Management Journal, 34(6), 686-700. https://doi.org/10.1016/j.emj.2016.06.011

Lehman, G. (2017). The language of environmental and social accounting research: The expression of beauty and truth. Critical Perspectives on Accounting, 44, 30-41. https://doi.org/10.1016/j.cpa.2016.11.005

McGuire, S. T., Omer, T. C., \& Sharp, N. Y. (2012). The impact of religion on financial reporting irregularities. Accounting Review, 87(2), 645-673. https://doi.org/10.2308/accr-10206

Milliman, J., Gatling, A., \& Kim, J. (Sunny). (2018). The effect of workplace spirituality on hospitality employee engagement, intention to stay, and service delivery. Journal of Hospitality and Tourism Management, 35 , $56-65$. https://doi.org/10.1016/j.jhtm.2018.03.002

Moura-Leite, R. C., \& Padgett, R. C. (2011). Historical background of corporate social responsibility. Social Responsibility Journal, 7(4), 528-539. https://doi.org/10.1108/1747111111117511

Muniapan, B., \& Satpathy, B. (2013). The "dharma" and "karma" of CSR from the Bhagavad-Gita. Journal of Human Values, 19(2), 173-187. https://doi.org/10.1177\%2F0971685813492265

Neuman, W. L. (2014). Social Research Methods: Qualitative and Quantitative Approaches (7th ed.). Essex, Inggris: Pearson.

Patton, M. Q. (2015). Qualitative Research \& Evaluation Methods: Integrating Theory and Practice. Thousand Oaks, CA: Sage.

Poulton, E., \& Barnes, L. (2012). Corporate social responsibility: An examination of business students' perceptions of spirituality. International Review of Business Research Papers, 8(4), 144-156. https://nova.newcastle.edu.au/vital/access/manage r/Repository/uon:23568

Roth, D., \& Sedana, G. (2015). Reframing Tri Hita Karana: From 'balinese culture' to politics. Asia Pacific Journal of Anthropology, 16(2), 157-175. https://doi.org/10.1080/14442213.2014.994674

Rotondo, F., Corsi, K., \& Giovanelli, L. (2019). The social side of sustainable business models: An explorative analysis of the low-cost airline industry. Journal of Cleaner Production, 225, 806-819. https://doi.org/10.1016/j.jclepro.2019.03.345

Simnett, R. (2012). Assurance of sustainability reports: Revision of ISAE 3000 and associated research opportunities. Sustainability Accounting, Management and Policy Journal, 3(1), 89-98. https://doi.org/10.1108/20408021211223570

Soobaroyen, T., \& Ntim, C. G. (2013). Social and environmental accounting as symbolic and substantive means of legitimation: The case of HIV/AIDS reporting in South Africa. Accounting Forum, 37(2), 92-109. https://doi.org/10.1016/j.accfor.2013.04.002

Suhardana, K. M. (2006). Pengantar Etika dan Moralitas Hindu. Surabaya: Paramita.

Vasilescu, R., Barna, C., Epure, M., \& Baicu, C. (2010). Developing university social responsibility: A model for the challenges of the new civil society. Procedia Social and Behavioral Sciences, 2(2), 4177-4182. https://doi.org/10.1016/j.sbspro.2010.03.660

Weinberg, F. J., \& Locander, W. B. (2014). Advancing workplace spiritual development: A dyadic mentoring approach. Leadership Quarterly, 25(2), 391408. https://doi.org/10.1016/j.leaqua.2013.10.009

Weinzimmer, L. G., \& Esken, C. A. (2016). Risky business: Taking a stand on social issues. Business Horizons, 59(3), 331-337. https://doi.org/10.1016/j.bushor.2016.01.007

Wiana, I. K. (2004). Mengapa Bali Disebut Bali? Surabaya: Paramita.

Wiana, I. K. (2007). Tri Hita Karana Menurut Konsep Hindu. Surabaya: Paramita.

World Commission on Environment and Development. (1987). Our Common Future. Oxford, Inggris: Oxford University Press. 